\title{
From islets of Langerhans to insulin analogs. It's been almost 100 years since the discovery of insulin
}

\section{ABSTRACT}

Until the discovery of insulin, diabetes was a fatal disease. The diet was the only form of treatment for this disease. Since the discovery of the Langerhans Islands, huge progress has been made in the treatment of diabetes. In 1921 due to Banting's research and collaborators, there has been a revolution in the treatment of diabetes. A disease that was once incurable could be controlled by insulin injections. Today insulin is not only a life-saving medicine. After the breakthrough discovery of scientists, research was conducted to improve insulin. Ultimately, these actions led to the creation of insulin analogs to make diabetes therapy even more perfect, by reducing the incidence of hypoglycemia. (Clin Diabetol 2019; 8, 5: 258-261)

Key words: insulin, diabetes, Paul Langerhans, Frederick Banting, insulin analogs

\section{Introduction}

Insulin is an anabolic peptide hormone produced and secreted by the beta cells of the pancreas. This hormone is involved in the metabolism of carbohydrates, fats, and proteins. Moreover, insulin influences

Address for correspondence:

lek. Aleksandra Cieluch

Katedra i Klinika Chorób Wewnętrznych i Diabetologii

Uniwersytet Medyczny im. Karola Marcinkowskiego w Poznaniu

Szpital Miejski im. Franciszka Raszei

ul. Mickiewicza 2, 60-834 Poznań, Poland

Phone/fax: 0048612245270

e-mail: aleksandra.cieluch@o2.pl

Clinical Diabetology 2019, 8, 5, 258-261

DOI: $10.5603 /$ DK.2019.0021

Received: 01.07.2019 Accepted: 08.07.2019 genes expression and has an antiapoptotic effect. In people with diabetes, depending on the type of the disease, there is a problem with its production in appropriate amounts or with proper functioning. In 1951, researchers and physicians Lawrence and Bornstein (United Kingdom) measured blood levels of insulin in 10 diabetic patients and recorded major differences in the results of these measurements. Researchers have observed a lack of insulin in young people, while in older and obese people, they found significant amounts of this hormone in the blood [1]. Modern medicine owes the discovery of insulin to many scholars who over the course of several decades have conducted a number of studies aimed at improving insulin therapy. Insulin-dependent diabetes, which for many hundreds of years was a fatal disease, has become a disease that could be treated, controlled more effectively, and reduced the adverse effects of its action on patients. Frederick Grant Banting is a scientist recognized as the discoverer of insulin. However, before him, there were many researchers who explored the topic of diabetes and who have gone down in the history of medicine. Term 'insulin' had been introduced by Jean de Meyer (1878-1934) in 1909 [2]. In this, he was followed by English physiologist Edward Albert Sharpey-Schafer (1850-1935), who in 1913, in lectures at Stanford University, he suggested the name 'insuline' for a substance in the islets of Langerhans then unknown [3]. Using radioimmunoassay technology, Solomon Berson, and Rosalyn Yalow in 1960 developed a method for measuring insulin in the blood. They observed that some people with diabetes still make their own insulin, and on this basis, they determined the occurrence of 'insulin-dependent' and 'non-insulin-dependent' diabetes [4]. 
The islets of Langerhans, or how did it begin?

The history of insulin therapy begins in 1869. The German 22-year-old medical student Paul Langerhans (1847-1888), while working on a microscope, identifies for the first time a group of cells within the pancreas, about which he writes: "(...) small cells of almost perfect homogeneous content and of a polygonal form, with round nuclei without nucleoli, mostly lying together in pairs or small groups" [5]. Langerhans admitted that he did not know the function of these special cells. The discovery of a student from Berlin did not find interest among scholars for many years, until 1893 when Gustav Laguesse bent over them. A group of cells was named by him 'Langerhans islands'. The scientist proposed that the pancreatic islets may play the endocrine role and produce a substance that reduces blood glucose levels [6]. The concept of 'pancreatic diabetes' was introduced in 1877 by Frenchman Etienne Lancereaux (1829-1910) [7]. In 1901, pathologist Eugene Lindsay Opie (1873-1971) described the occurrence of hyaline degeneration within the Langerhans islands in diabetes. At the same time, he hypothesized that these changes may condition the occurrence of the disease [8]. Despite the above-mentioned discoveries, the substance produced by the pancreas has not yet been used as a drug in people with diabetes. However, the researchers attempted to isolate island secretion, which proved to be ineffective. The German physician George Ludwig Zuelzer (1870-1949) obtained and applied pancreatic extract for the first time in 1906. The results of the experiment were promising at first because the sugar was reduced or the total disappearance of sugar from the urine was observed. However, the preparation caused side effects in the form of allergic-toxic reactions and hypoglycemia [9]. On 28 May 1912, Zuelzer patented his method in the United States. In contrast, Dr. Ernest Scott (1877-1966) (University of Chicago) in 1911 and Israel Kleiner (1885-1966) (Rockefeller University in New York) in 1919, giving an aqueous extract of the pancreas to dogs, obtained a temporary reduction of glucose level in urine and blood [10, 11]. Romanian professor of physiology Nicolas Paulesco (1869-1931) (Medical University of Bucharest) in 1916 refined the acquisition of aqueous extract from the pancreas, which in diabetic dogs had a normalizing effect on sugar level in the blood and urine. In addition, he observed a decrease in urea in the blood and urine. In 1921 Paulescu published his data in two prominent French journals, eight months before the first publication of Banting and Best from February 1922 [12]. Unfortunately, the work of scientists interrupted the outbreak of World War I or the disapproval of university authorities. De- spite attempts to isolate the substance that reduces blood glucose, it has not been able to be used in clinical practice. However, these studies have had a huge impact on further work leading to the final isolation of insulin and its administration to the patient. By the time of significant progress in the treatment of diabetes, i.e. the nineteenth and twentieth centuries, it was not possible to determine what causes diabetes, and it was not known how to treat it. People with diabetes died from exhaustion and due to complications. The only known treatment at that time was diet.

\section{The breakthrough time has come...}

The discovery of insulin by Canadian scientists changed the treatment of diabetes completely and improved the prognosis of patients. It was a breakthrough moment, a milestone in the history of diabetes and one of the greatest achievements in medicine. In addition to research activities, Frederick Grant Banting (1891-1941), a young orthopedic surgeon, lectured for medical students. In October 1920, when preparing for a lecture on the subject of the pancreas, he found an article about pancreatolithiasis. Due to the mechanical blockade of pancreatic ducts, the disease caused atrophy of cells secreting digestive enzymes, but the function of the islets of Langerhans remained unchanged. Mering and Minkowski, in their experiments, ligated pancreatic ducts in dogs, which caused similar results. This prompted Banting to repeat the experiment. The dogs examined had the pancreas removed or ligated pancreatic ducts. The pancreas with ligated ducts underwent the extraction process and the solution he obtained was injected into diabetic dogs. Banting observed a short-term reduction in the glucose level in the blood and urine, which resulted from contamination of the extract by digestive enzymes. In addition, adverse reactions at the injection site in the form of abscesses were observed due to the administration of a poorly purified pancreatic extract. Banting's colleague suggested re-conducting experiments in a specialized laboratory at the University of Toronto under the supervision of medical professor John James Richard Macleod (1876-1935), a well-known Scottish physiologist and diabetes specialist from Aberdeen. Macleod was one of the greatest specialists in the field of carbohydrate metabolism. In the spring of 1921, Macleod agreed to make the laboratory and experimental animals available to Banting and offered him the assistance of two medical students, Charles Herber Best (1899-1978) and Edward Clark Noble. Best became Banting's closest associate, and their work in the Toronto laboratory resulted in exceptional results. The extract obtained by the researchers, which they called the isletine, was 
subjected to purification at the request of Professor Macleod. This task belonged to the Canadian biochemist James Bertram Collip (1892-1965). Obtaining a maximum purified and minimally toxic pancreatic extract allowed for its clinical use and subcutaneous administration to a diabetic patient. This treatment saved the life of 14 year-old Leonard Thompson, a native of Toronto. The boy had diabetes for three years and his body weight was only 30 kilograms. Leonard was in a diabetic coma, in which he collapsed and woke up alternately. His father agreed to give his son a newly discovered drug, previously tested on animals. The first injection of insulin occurred on 11 January 1922. However, its first clinical application did not bring about a spectacular effect, because only a $25 \%$ reduction in glucose was obtained. In addition, glucose and ketone bodies remained in the urine of the patient. An abscess appeared at the injection site, and the patient developed a severe allergic reaction to the newly discovered drug. Insulin therapy was considered ineffective, but the researchers decided to improve the effectiveness of the discovered drug. Cooperation with Connaught Laboratories allowed for achievement the more purified insulin. On 23 January 1922, the obtained preparation was given to the boy in several injections a day. Then the expected effect was observed - the glucose concentration dropped significantly in the blood and urine. Also, the symptoms of diabetic acidosis have disappeared, which was accompanied by the complete disappearance of ketone bodies in the urine. The boy died at the age of 27, but the cause of his death was not diabetes and its complications, but pneumonia. Researchers continued testing the extract and in February 1922 qualified six people for treatment, but in these cases, the treatment was successful [13-19]. For the first time, the researchers announced the results of their work in May 1922 during the meeting of the Association of American Physicians. Discoverers were represented by Macleod, who talked about the discovery and use of insulin. Soon the production of insulin on a large scale began. The first company that chose to do this was the Connaught Laboratories in Indianapolis, but the insulin they produced was ineffective clinically. Another company that took up the challenge was Eli Lilly from Toronto. They were stronger than their predecessors because production was very large, but also their activity proved to be ineffective. In November 1922 the cause of the lack of efficacy of insulin produced by Lilly was discovered. Their chief chemist George Walden found that insulin was reduced in purity due to precipitation at the improper $\mathrm{pH}$ [20]. However, failures in the production process were not the only obstacles. These were eliminated, while issues such as production standardization or patent law remained to be resolved. The interest in insulin has reached large proportions and its production has been taken up by numerous scientific and commercial centers. One of them was a non-profit body, the Nordisk Insulin Laboratory, which is currently one of the leading insulin companies. This undertaking was initiated in 1923 by an eminent physiologist Nobel laureate for research on metabolism and physical effort, August Krogh from the University of Copenhagen, whose wife was diabetic. During a meeting with Banting and Macleod, he got the knowledge of insulin and received authorization from the University of Toronto to bring insulin to Scandinavia [21]. During the work on the discovery of insulin, there were conflicts between the members of the research team. The source of the conflict was the first public report on the results of the experimental treatment of diabetes in animals with a partially purified solution of insulin. Macleod wanted to be recognized as a leading researcher, while Banting's position in the medical world was not strong enough. However, both scientists were noticed and honored. In 1923, Banting and MacLeod received the Nobel Prize in medicine and physiology. However, they did not forget about their closest collaborators, without which we would not use insulin today. Banting donated half of the award to Charles Herbert Best, while MacLeod shared the prize with James Bertram Collip. Never before has a scientist received the Nobel Prize in such a short time after the discovery.

\section{From NPH insulin to analogs}

Insulin derived from animals has been used to treat diabetes for many years. Despite the effectiveness and increase in survival, insulin was not devoid of imperfections due to the occurrence of allergic reactions in many patients. Research has been carried out on improving insulin. One of the shortcomings of insulin therapy at the time was the necessity of administering the drug in several injections a day. The researchers sought to create long-acting insulin. The year 1936 is the time when the long-acting insulin, containing an admixture of protein - protamine, was first developed. This was accomplished by the assistant of August Krogh, Hans Christian Hagedorn. The preparation was named as insulin with a prolonged action type NPH (neutral protamine Hagedorn) [22]. At the same time, in Toronto Scott and Fisher further prolonged the effect of insulin by adding zinc [23]. These findings led to the launch of longer-acting animal insulins. The world of science got to know insulin more and more. In 1955, a scientist from the University of Cambridge, Frederick Sanger determined the amino acid sequence of insulin, for which he received the Nobel Prize [24]. The year 1958 
is also a breakthrough in genetic engineering because insulin as the first protein was successfully synthesized chemically as the first drug produced by genetic engineering methods. In 1959, Paul Lacy confirmed with immunohistochemistry that the cell responsible for the production of insulin is the $\beta$ cell [25]. In 1969, Dorothy Hodgkin of the University of Cambridge determined the spatial structure of the insulin molecule, for which she was awarded the Nobel Prize.

The era of human insulins and their analogs have come. In 1978, David Goeddel, Ph.D., and colleagues at Genentech prepared the first recombinant human insulin by utilizing and combining the insulin A- and B-chains expressed in Escherichia coli. Afterward, Genentech and Lilly signed an agreement to commercialize human insulin produced by recombinant DNA. The first recombinant insulins launched in 1982 were Humulin R (short-acting) and N (NPH, intermediate-acting) [26]. To make diabetes therapy even more perfect, by reducing the incidence of hypoglycemia, insulin preparations were sought that mimicked the physiological secretion of insulin. The change in pharmacokinetics due to the modification of the amino acid site in insulin led to the formation of insulin analogs. These insulins were characterized by faster absorption and shorter duration of action. The first rapid-acting analog of insulin introduced to the market in 1996 was lispro. In 2000 and 2005, aspart and glulisine were introduced respectively. In contrast, long-acting insulin analogs were approved in 2000 (glargine) and 2005 (detemir). The next generation of insulin analogs are ultralong-acting insulin analogs glargine U300 and degludec (2015).

\section{Conclusions}

Over the decades, there has been undeniable progress in the treatment of diabetes. The disease, once considered deadly, become a chronic disease. However, complications of diabetes continue to be an important problem. Insulin has become a drug of opportunity for people with diabetes, and its continuous refinements have made metabolic control of the disease often achieved perfectly.

\section{Conflict of interest}

The authors declare no conflict of interest.

\section{REFERENCES}

1. Bornstein J, Lawrence RD. Plasma insulin in human diabetes mellitus. Br Med J. 1951; 2(4747): 1541-1544, doi: 10.1136/ /bmj.2.4747.1541, indexed in Pubmed: 14879146.

2. De Meyer J. Action de la sécrétion interne du pancréas sur différents organes et en particulier sur la sécrétion rénale. Arch Fisiol. 1909; 7: 96-99.
3. Schäfer EA. An introduction to the study of the endocrine glands and internal secretions. Stanford University, Palo Alto 1914: 18, 84, 86.

4. Yalow RS, Berson SA. Immunoassay of endogenous plasma insulin in man. J Clin Invest. 1960; 39: 1157-1175, doi: 10.1172/ JCl104130, indexed in Pubmed: 13846364.

5. Sakula A. Paul Langerhans (1847-1888): a centenary tribute. J R Soc Med. 1988; 81(7): 414-415, indexed in Pubmed: 3045317.

6. Goet JP. Gustave Edouard Laguesse; his demonstration of the significance of the Islands of Langerhans. Diabetes. 1953; 2(4): 322-324, doi: 10.2337/diab.2.4.322, indexed in Pubmed: 13083474.

7. Lancereaux $E$. Note et réflexions sur deux cas de diabète sucré avec alteration du pancréas. Bull Acad Méd. 1877; 6(2): 1215.

8. Opie EL. The relation oe diabetes mellitus to lesions of the pancreas. Hyaline degeneration of the islands oe langerhans. J Exp Med. 1901; 5(5): 527-540, doi: 10.1084/jem.5.5.527, indexed in Pubmed: 19866956.

9. Zuelzer G. Ueber Versuche einer specifischen Fermenttherapie des Diabetes. Zeitschrift fü Experimentelle Pathologie und Therapie. 1908; 5(2): 307-318, doi: 10.1007/bf02661302

10. Scott $E$. On the influence of intravenous injections of an extract of the pancreas on experimental pancreatic diabetes. Am J Physiol. 1912; 29(3): 306-310, doi: 10.1152/ajplegacy.1912.29.3.306.

11. Kleiner IS. The action of intravenous injections of pancreas emulsions in experimental diabetes. J Biol Chem. 1919; 40: 153-170.

12. Ionescu-Tirgoviste C, Buda O. Nicolae Constantin Paulescu: the first explicit description of the internal secretion of the pancreas. Acta Med Hist Adriat. 2017; 15(2): 303-322, doi: 10.31952/ /amha.15.2.8, indexed in Pubmed: 29402120.

13. Tan SY, Merchant J. Frederick Banting (1891-1941): Discoverer of insulin. Singapore Med J. 2017; 58(1): 2-3, doi: 10.11622/ /smedj.2017002, indexed in Pubmed: 28111693.

14. Stylianou C, Kelnar C. The introduction of successful treatment of diabetes mellitus with insulin. J R Soc Med. 2009; 102(7): 298-303, doi: 10.1258/jrsm.2009.09k035, indexed in Pubmed: 19605862.

15. Vecchio I, Tornali C, Bragazzi NL, et al. The discovery of insulin: an important milestone in the history of medicine. Front Endocrinol (Lausanne). 2018; 9: 613, doi: 10.3389/fendo.2018.00613, indexed in Pubmed: 30405529.

16. Karamanou M, Protogerou A, Tsoucalas G, et al. Milestones in the history of diabetes mellitus: the main contributors. World J Diabetes. 2016; 7(1): 1-7, doi: 10.4239/wjd.v7.i1.1, indexed in Pubmed: 26788261.

17. Rosenfeld L. Insulin: discovery and controversy. Clin Chem. 2002; 48(12): 2270-2288, indexed in Pubmed: 12446492

18. Unger J. Diabetes managementt in primary care. Lippincott Williams \& Wilkins, Philadelphia 2007.

19. Holt RIG, Cockram C, Flyvbjerg A, et al. Textbook of diabetes. Fifth edition. Wiley-Blackwell, Hoboken 2016.

20. Hilgenfeld R, Seipke G, Berchtold H, et al. The evolution of insulin glargine and its continuing contribution to diabetes care. Drugs. 2014; 74(8): 911-927, doi: 10.1007/s40265-014-0226-4, indexed in Pubmed: 24866023.

21. Poulsen JE. The impact of August Krogh on the insulin treatment of diabetes and our present status. Acta Med Scand Suppl. 1975; 578: 7-14, indexed in Pubmed: 1098401.

22. Hagedorn HC, Jensen BN, Krarup NB. Protamine insulinate. J Am Med Assoc. 1936; 106(3): 177, doi: 10.1001/ jama.1936.02770030007002.

23. Scott $D$, Fisher $A$. The prolongation of insulin action by protamine and zinc. Proc Am Soc Biol Chem. 1936; 88: 8

24. Berg P. Fred Sanger: a memorial tribute. Proc Natl Acad Sci U S A. 2014; 111(3): 883-884, doi: 10.1073/pnas.1323264111, indexed in Pubmed: 24449828.

25. Lacy PE. Electron microscopy of the islets of Langerhans. Diabetes. 1962; 11: 509-513.

26. Goeddel DV, Kleid DG, Bolivar F, et al. Expression in Escherichia coli of chemically synthesized genes for human insulin. Proc Natl Acad Sci USA. 1979; 76(1): 106-110, doi: 10.1073/pnas.76.1.106, indexed in Pubmed: 85300. 
